\title{
Indirect Regeneration of Japonica Rice (Oryza sativa L.) Varieties through Anther Culture
}

\author{
Avinash Sharma ${ }^{1 *}$, Dalpat Lal ${ }^{1}$, Monoj Sutradhar ${ }^{1}$, Hansraj Pradhan ${ }^{2}$ and \\ Nirupa Kumari ${ }^{3}$ \\ ${ }^{I}$ Department of Plant Biotechnology, University of Agricultural Sciences, GKVK, Bengaluru, \\ Karnataka, India \\ ${ }^{2}$ Department of Crop Improvement, CSKHPKV, Palampur, India \\ ${ }^{3}$ Department of Botany, Patna University, India \\ *Corresponding author
}

\begin{abstract}
A B S T R A C T
Keywords

Anther, Japonica rice,

Cold pre-treatment,

Callus induction, Shoot regeneration

Article Info

Accepted:

06 July 2018

Available Online:

10 August 2018

Effect of growth regulators on frequency of callus induction and shoot regeneration from anthers of two japonica rice varieties viz., Azucena and Moroberekan were studied. Anthers from panicles in which the distance between flag leaf and subtending leaf was 12$13 \mathrm{~cm}$ in Azucena and 14-15 cm in Moroberekan were selected for culture. At this stage of development, anthers contained mid-uninucleate pollen grains. Panicles were subjected to cold pre-treatment of $4^{\circ} \mathrm{C}$ for 8 days. Higher callus induction frequency $49.99 \%$ and 48.64 $\%$ obtained on N6 medium containing $2 \mathrm{mg} / \mathrm{L} \mathrm{2,4-D}+1 \mathrm{mg} / \mathrm{L}$ Kinetin $\left(\mathrm{T}_{4}\right)$ and $1 \mathrm{mg} / \mathrm{L}$ 2,4-D + $2 \mathrm{mg} / \mathrm{L} \mathrm{NAA}+0.5 \mathrm{mg} / \mathrm{L}$ Kinetin $\left(\mathrm{T}_{11}\right)$ however, higher shoot regeneration frequency $83.99 \%$ and $80.00 \%$ obtained on MS medium containing $0.5 \mathrm{mg} / \mathrm{L} \mathrm{Kinetin}+2$ $\mathrm{mg} / \mathrm{L} \mathrm{BAP}\left(\mathrm{T}_{10}\right)+1 \mathrm{mg} / \mathrm{L} \mathrm{NAA}$ and $2 \mathrm{mg} / \mathrm{L} \mathrm{Kinetin}+1 \mathrm{mg} / \mathrm{L} \mathrm{BAP}+1 \mathrm{mg} / \mathrm{L} \mathrm{NAA}\left(\mathrm{T}_{16}\right)$ in Azucena and Moroberekan respectively. The present results indicated the anther culture is influence by the genotypes and media composition and this investigation also can be used in the DH (Double Haploid) production in rice.
\end{abstract}

\section{Introduction}

Rice (Oryza sativa $\mathrm{L} ., 2 \mathrm{n}=24$ ) is an important cereal crop belong to the family Poaceae. It is one of the major food crops of the world and it is the staple diet of about half of the world's population. The crop is grown in about 162.9 million hectares worldwide with a total production of 744.6 million tonnes. In India, it is grown in an area of 38.03 million hectares with an annual production of 155 million tonnes and productivity of $3623.12 \mathrm{~kg} / \mathrm{ha}$.
India ranks second in total rice production after China (FAOSTAT, 2014). Over 75 per cent of the world supply is consumed by people in Asian countries and thus rice is of immense importance to food security of Asia. In India, with an average annual population growth rate of approximately 1.6 per cent and estimated per capita consumption of about 250 $\mathrm{g}$ of rice per day, the demand for rice is expected to increase by 40 per cent by 2025 (Khush, 2005). However, hybrids and varieties developed by conventional breeding methods 
are not sufficient to fulfill the demands of growing population. Furthermore, development of new biotechnological tools like anther culture, embryo rescue and somaclonal variation prove to be very efficient and quick solution for development of improved rice varieties in short time period. Haploid may be induced by different techniques, the most promising and successful one being anther culture (androgenesis). It is the fastest method of doubled haploid production as it takes only three years (Tadesse et al., 2013). DH is a technique that manipulates microspore cells in immature anthers, to induce haploid callus formation, which are subsequently converted to double haploid embryos. It is applied to accelerate the process of obtaining pure lines, thus shortening breeding cycle by immediate fixation of homozygosity, easy selection of phenotypes for quantitative characters with increased selection efficiency, widening of genetic variability through the production of gametoclonal variants and allowing early expression of recessive genes. In addition, screening of haploid cells against cold tolerance, salinity, pathotoxins and other biotic and abiotic factors before plant regeneration are possible. Haploids are also valuable to detect and fix desirable recessive traits introduced through mutation (Chen et al., 2001) or hybridization (He et al., 2006). Anther culture in japonica rice has very high success rate than indica rice because the maturity of tissue culture in indica rice lags behind that of japonica rice. The low success rate with anther cultures in indica rice varieties limits the application of anther culture for crop improvement in indica genotypes (Niroula and Bimb, 2009). There are two pathways in androgenesis from pollen grains: direct and indirect androgenesis. The direct pathway involves microspore differentiation through a series of stages that stimulate direct embryogenesis without intervening callus phase. The indirect pathway involves the formation of callus from the microspore, which bursts through the anther wall, and then differentiates to form either embryos or organogenesis (Reed, 2005). The development of microspores into fertile plants in in vitro androgenesis depends upon several factors such as genotype, growing conditions of the donor plants, pretreatment of panicles, anther condition, developmental stage of microspores, culture media, growth regulators and various environmental conditions. Although japonica subspecies of Oryza sativa $\mathrm{L}$. is responsive to androgenesis, but there is difference in response among japonica varieties. Hence, there is further need to study the influence of factors such as auxin and cytokinin in the media that favour the production of high quantity callus in a shorter time and regeneration of greater number of plants per culture unit. The objective of the present investigation was to study the effect of growth regulators on callus induction and regeneration in japonica rice varieties through anther culture.

\section{Materials and Methods}

\section{Plant material}

Two japonica rice varieties Azucena (Tropical and deep rooted, aromatic with high $\mathrm{Fe}$ and $\mathrm{Zn}$ content) and Moroberekan (Tropical, drought tolerant, high $\mathrm{Fe}, \mathrm{Zn}$ content and blast resistance) grown in Kharif season on field and used as the source of explants. Recommended fertilizers and plant protection measures were adopted to raise healthy plants.

\section{Selection of explant}

Panicles were harvested at the early flowering stage, when young panicles were still enclosed within the leaf sheath. Panicles with a maximum distance between the subtending leaf and the flag leaf, of $12-13 \mathrm{~cm}$ for Azucena and $14-15 \mathrm{~cm}$ for Moroberekan were selected. 
Panicles were collected between 6.00-9.00 am and washed with water and sprayed with 70 per cent ethanol. These panicles were sealed in a polyethylene bag and were wrapped in aluminum foil. Cold pre-treatment was given by placing them in refrigerator at $4^{\circ} \mathrm{C}$ for 8 days (Dalpat et al., 2014). In order to identify the stage of pollen development, anthers of both varieties were stained with acetocarmine and observed under light microscope. The spikelets in the middle and bottom position of panicle which contained the pollen grain mostly in the mid uninucleate stage were selected for culturing.

\section{Sterilization and inoculation of explant}

The panicles were surface sterilized by immersion in $70 \%(\mathrm{v} / \mathrm{v})$ ethanol for 20 seconds followed by $0.2 \% \mathrm{HgCl}_{2}$ for 10 minutes. The treated panicles were washed 3-4 times with sterile distilled water.

Later, the anthers were isolated from spikelet avoiding any mechanical damage, followed by inoculation in bottles, each containing $30 \mathrm{ml}$ of solidified solid N6 medium containing 3\% maltose and $0.8 \%$ agar for callus induction [Fig. 1(1A, 1B)].

The medium was supplemented with different concentrations and combination of growth hormones. The cultures were sealed with parafilm and kept in dark at $23 \pm 2^{\circ} \mathrm{C}$. The cultures were observed frequently and the contaminated plates were removed. The observations were recorded from 8 to 20 weeks of culture. Observations were number of anthers inoculated, weeks taken for callusing, colour of the callus and callus induction frequency $(\%)$.

Callus

No. of anthers producing callus

Induction frequency $(\%)=$

No. of anthers plated

\section{Regeneration}

The anther derived calli were transferred to bottles containing $30 \mathrm{ml}$ of solidified regeneration MS (Murashige and Skoog) medium consisting of $3 \%$ sucrose and $0.8 \%$ agar with different growth regulators concentrations and combination was added to the media. The $\mathrm{pH}$ of the both media for callus induction and regeneration was adjusted to 5.8 with $1 \mathrm{~N} \mathrm{HCl}$ or $1 \mathrm{~N} \mathrm{NaOH}$ before adding agar and autoclaving. The plated calli were incubated in culture room at $23 \pm 2^{\circ} \mathrm{C}$ with $16-\mathrm{h}$ of light, at light intensity of about 3000 Lux. Observations were recorded as number of callus transferred, time taken for regeneration (days), colour of regenerated plantlet (Green/ Albino) and regeneration frequency (\%) after 30 days of culture.

No. of regenerated plantlet Regeneration frequency $(\%)=$ No. of calli plated for regeneration

\section{Data analysis}

All the experiments were conducted in the plant tissue culture laboratory, under uniform condition of temperature, humidity and light. For each treatment used in the experiment, three replications were maintained and data were analysed by Factorial Completely Randomized Design method for callus induction and regeneration.

\section{Results and Discussion}

Rice is one of the most important crops of Asia and it is the staple food of more than 90 per cent of the Asian population. The productivity of rice has to be improved upon continuously to meet the requirement of ever increasing population. This cannot be achieved through conventional techniques of crop improvement only and will require the involvement of plant biotechnology, including 
tissue culture. Many new rice cultivars have been developed through biotechnological techniques like anther culture, embryo rescue and somaclonal variation (Brown and Thorpe, 1995; Zapata et al., 2004). Several studies has been reported on rice anther culture (Xie et al., 1995; Sengsai et al., 2007; Sah, 2008; Chen and Qin, 2008 and Dalpat et al., 2014).

\section{Panicle harvest stage}

The panicles were harvested at the early flowering stage when young panicles were still enclosed within the sheath. Panicles with a distance of 12-13 cm between flag leaf and subtending leaf for Azucena and 14-15 cm for Moroberekan were selected, because at this stage of panicle development microspores were in the mid-uninucleate stage and it is considered to be the optimum stage of pollen development for callus induction. Mercy and Zapata, (1986) studied the distance between flag leaf and subtending leaf as well as the late uninucleate and early binucleate pollen stage.

Several workers have been reported that late and mid- uninucleate stage of microspores in japonica rice was better for callus induction (Xie et al., 1995; Chen et al., 2001; Joong and Seung, 2002; Sengsai et al., 2007; Sah, 2008; Niroula and Bimb, 2009 and Dalpat et al., 2014). Panicles with a distance of $11-13 \mathrm{~cm}$ (Afza et al., 2000); 7-22 cm (Prabhu, 2013) and $8-11 \mathrm{~cm}$ (Dalpat et al., 2014) between flag leaf and subtending leaf have been used successfully for callus induction in different japonica rice varieties.

\section{Cold pre-treatment and dark incubation}

In the present study, cold pre-treatment at $4{ }^{\circ} \mathrm{C}$ for 8 days was given for the selected panicles. The cultures were incubated in dark for 10-20 weeks for enhancing callus induction frequency (Cai and Chen, 1984; Trejo-Tapia et al., 2002). Sunderland and Dunwell (1974) reported that cold pre-treatment assures survival of a greater proportion of the embryogenic pollen grains. The total content of free amino acids is increased in dark, which might be conductive for adaptation of microspores to the metabolic changes that results in embryogenesis induction (Claparols et al., 1993; Xie et al., 1997). Kaushal et al., (2014) reported that cold treatment is essential to improve anther culture response and manipulation of pre-treatment has ability to improve callus induction and subsequent plant regeneration.

Cold treatments enhanced stoppage of the gametophytic development of microspores during cold stress and guides continuous division of the microspores to form callus (Tourev et al., 1996 and Heberle-Bors, 1996). According to several reports cold pretreatment longer than 11 days showed albino plants (Pande, 1997; Sen et al., 2011) and decline in green plantlet regeneration capabilities of the calli of japonica rice (Chung, 1987 and Zhang, 1989).

\section{Callus induction}

The cultured anthers started turning brown after 3-4 weeks of culturing. The first indication of callus initiation was swelling of the anther wall followed by emergence of microcalli from anther lobes. Later callus appeared from the cut ends. These indications of callus induction support to Gupta and Borthakar, (1987) and Dalpat et al., (2014). It took 10-20 weeks for callus induction. The effect of growth regulators on androgenic callus induction in japonica rice varieties is presented in Table 1. Among the two varieties, the mean of percent callus induction frequency was (14.39\%); (9.31\%) in Moroberekan and Azucena respectively. The kind and concentrations of growth regulators (Auxin and Cytokinins) are known to play an important role in androgenic callus response. 
Table.1 Effect of growth regulators on callus induction in japonica rice varieties

\begin{tabular}{|c|c|c|c|c|c|c|c|c|}
\hline \multirow[t]{2}{*}{ Treatment } & \multirow{2}{*}{$\begin{array}{c}\text { 2,4-D } \\
(\mathrm{mg} / \mathrm{L})\end{array}$} & \multirow{2}{*}{$\begin{array}{l}\text { NAA } \\
(\mathbf{m g} / \mathbf{L})\end{array}$} & \multirow{2}{*}{$\begin{array}{l}\text { Kinetin } \\
(\mathrm{mg} / \mathrm{L})\end{array}$} & \multicolumn{2}{|c|}{ No. of anthers inoculated* } & \multicolumn{2}{|c|}{ Callus induction (\%)* } & \multirow{2}{*}{$\begin{array}{l}\text { Mean of } \\
\text { treatment }\end{array}$} \\
\hline & & & & Azucena & Moroberekan & Azucena & Moroberekan & \\
\hline $\mathrm{T}_{0}($ Control $)$ & 0 & 0 & 0 & 28.33 & 38.66 & $0.00(0.70)$ & $0.00(0.70)$ & $0.00(0.70)$ \\
\hline$T_{1}$ & 1 & 0 & 0.5 & 34.00 & 25.00 & $5.88(2.52)$ & $0.00(0.70)$ & $2.94(1.61)$ \\
\hline$T_{2}$ & 1 & 0 & 1 & 56.66 & 52.66 & $0.00(0.70)$ & $17.09(4.18)$ & $8.55(2.44)$ \\
\hline $\mathbf{T}_{3}$ & 2 & 0 & 0.5 & 69.00 & 38.66 & $2.89(1.83)$ & $7.75(2.86)$ & $5.33(2.35)$ \\
\hline$T_{4}$ & 2 & 0 & 1 & 27.66 & 36.66 & $49.99(7.10)$ & $19.09(4.42)$ & $34.54(5.76)$ \\
\hline$T_{5}$ & 0 & 1 & 0.5 & 38.66 & 47.66 & $10.34(3.29)$ & $6.29(2.60)$ & $8.32(2.94)$ \\
\hline$T_{6}$ & 0 & 1 & 1 & 40.33 & 53.33 & $9.91(3.21)$ & $13.12(3.68)$ & $11.52(3.45)$ \\
\hline $\mathbf{T}_{7}$ & 0 & 2 & 0.5 & 53.00 & 45.00 & $5.66(2.46)$ & $2.22(1.63)$ & $3.94(2.05)$ \\
\hline$T_{8}$ & 0 & 2 & 1 & 35.66 & 47.00 & $11.21(3.41)$ & $10.68(3.34)$ & 10.95 \\
\hline$T_{9}$ & 1 & 1 & 0.5 & 38.33 & 54.66 & $0.00(0.70)$ & $16.46(4.11)$ & $8.23(2.41)$ \\
\hline $\mathrm{T}_{10}$ & 1 & 1 & 1 & 47.00 & 38.33 & $2.12(1.60)$ & $2.60(1.75)$ & $2.36(1.67)$ \\
\hline$T_{11}$ & 1 & 2 & 0.5 & 38.66 & 37.00 & $18.10(4.30)$ & $48.64(7.01)$ & $33.38(5.65)$ \\
\hline$T_{12}$ & 1 & 2 & 1 & 36.00 & 41.66 & $5.55(2.44)$ & $4.80(2.30)$ & $5.18(2.37)$ \\
\hline$T_{13}$ & 2 & 1 & 0.5 & 63.66 & 43.33 & $3.14(1.89)$ & $39.23(6.30)$ & $21.19(4.09)$ \\
\hline$T_{14}$ & 2 & 1 & 1 & 33.33 & 43.33 & $12.00(3.53)$ & $16.15(4.07)$ & $14.08(3.80)$ \\
\hline$T_{15}$ & 2 & 2 & 0.5 & 53.66 & 46.00 & $9.31(3.12)$ & $17.39(4.22)$ & $13.35(3.67)$ \\
\hline$T_{16}$ & 2 & 2 & 1 & 57.00 & 51.66 & $12.20(3.56)$ & $23.22(4.87)$ & $17.71(4.21)$ \\
\hline \multicolumn{6}{|l|}{ Mean of var } & $9.31(2.73)$ & $14.39(3.45)$ & \\
\hline
\end{tabular}

Data are in angular transformed values with correction factor of $0.5 \%$

$\mathrm{SEM} \pm 0.185$

$\mathrm{CV}=5.60$

$\mathrm{CD}(1 \%)=0.40$

Legend: * Average of 3 replication

Table.2 Regeneration from androgenic callus of japonica rice varieties

\begin{tabular}{|c|c|c|c|c|c|c|c|c|c|c|}
\hline \multirow[t]{2}{*}{ Treatment } & \multirow[t]{2}{*}{$\begin{array}{l}\text { Kinetin } \\
(\mathrm{mg} / \mathrm{L})\end{array}$} & \multirow[t]{2}{*}{$\begin{array}{c}\text { BAP } \\
(\mathbf{m g} / \mathrm{L})\end{array}$} & \multirow[t]{2}{*}{$\begin{array}{l}\text { NAA } \\
(\mathbf{m g} / \mathbf{L})\end{array}$} & \multicolumn{2}{|c|}{$\begin{array}{l}\text { No. of calli } \\
\text { plated }\end{array}$} & \multicolumn{2}{|c|}{$\begin{array}{l}\text { Regeneration Frequency } \\
\qquad(\%)\end{array}$} & \multirow[t]{2}{*}{$\begin{array}{l}\text { Mean of } \\
\text { treatment }\end{array}$} & \multicolumn{2}{|c|}{$\begin{array}{l}\text { Colour of } \\
\text { regenerated } \\
\text { shootlet }\end{array}$} \\
\hline & & & & Azu & Moro & Azu & Moro & & Azu & Moro \\
\hline $\begin{array}{c}\mathrm{T}_{0} \\
\text { (Control) }\end{array}$ & 0 & 0 & 0 & 0 & 0 & $0.00(0.70)$ & $0.00(0.70)$ & $0.00(0.70)$ & - & - \\
\hline$T_{1}$ & 0.5 & 0 & 0.5 & 23 & 9 & $0.00(0.70)$ & $0.00(0.70)$ & $0.00(0.70)$ & - & - \\
\hline$T_{2}$ & 0.5 & 0 & 1 & 7 & 7 & $0.00(0.70)$ & $0.00(0.70)$ & $0.00(0.70)$ & - & - \\
\hline$T_{3}$ & 1 & 0 & 0.5 & 4 & 10 & $0.00(0.70)$ & $50.00(7.10)$ & $25.00(3.90)$ & - & G \\
\hline$T_{4}$ & 1 & 0 & 1 & 4 & 7 & $0.00(0.70)$ & $28.57(5.39)$ & $14.29(3.04)$ & - & A \\
\hline$T_{5}$ & 2 & 0 & 0.5 & 3 & 3 & $0.00(0.70)$ & $33.33(5.81)$ & $16.67(3.26)$ & - & A \\
\hline$T_{6}$ & 2 & 0 & 1 & 8 & 4 & $50.00(7.10)$ & $0.00(0.70)$ & $25.00(3.90)$ & A & - \\
\hline $\mathbf{T}_{7}$ & 0.5 & 1 & 0.5 & 6 & 8 & $0.00(0.70)$ & $0.00(0.70)$ & $0.00(0.70)$ & - & - \\
\hline $\mathrm{T}_{8}$ & 0.5 & 1 & 1 & 9 & 9 & $0.00(0.70)$ & $0.00(0.70)$ & $0.00(0.70)$ & - & - \\
\hline$T_{9}$ & 0.5 & 2 & 0.5 & 2 & 6 & $0.00(0.70)$ & $0.00(0.70)$ & $0.00(0.70)$ & - & - \\
\hline$\overline{T_{10}}$ & 0.5 & 2 & 1 & 6 & 9 & $83.33(9.15)$ & $55.55(7.48)$ & $69.44(4.83)$ & A & G \\
\hline$\overline{T_{11}}$ & 1 & 1 & 0.5 & 2 & 13 & $0.00(0.70)$ & $0.00(0.70)$ & $0.00(0.70)$ & - & - \\
\hline$T_{12}$ & 1 & 1 & 1 & 2 & 9 & $0.00(0.70)$ & $0.00(0.70)$ & $0.00(0.70)$ & - & - \\
\hline$T_{13}$ & 1 & 2 & 0.5 & 2 & 10 & $0.00(0.70)$ & $0.00(0.70)$ & $0.00(0.70)$ & - & - \\
\hline$T_{14}$ & 1 & 2 & 1 & 6 & 17 & $0.00(0.70)$ & $0.00(0.70)$ & $0.00(0.70)$ & - & - \\
\hline$T_{15}$ & 2 & 1 & 0.5 & 4 & 7 & $0.00(0.70)$ & $0.00(0.70)$ & $0.00(0.70)$ & - & - \\
\hline$T_{16}$ & 2 & 1 & 1 & 19 & 5 & $0.00(0.70)$ & $80.00(8.97)$ & $40.00(4.83)$ & - & G \\
\hline$\overline{T_{17}}$ & 2 & 2 & 0.5 & 5 & 9 & $0.00(0.70)$ & $0.00(0.70)$ & $0.00(0.70)$ & - & - \\
\hline$T_{18}$ & 2 & 2 & 1 & 7 & 14 & $0.00(0.70)$ & $0.00(0.70)$ & $0.00(0.70)$ & - & - \\
\hline \multicolumn{6}{|c|}{ Mean of variety } & $7.01(1.48)$ & $13.02(2.35)$ & & & \\
\hline
\end{tabular}

Data are angular transformed values with correction factor of $0.5 \%$

$\mathrm{SEM} \pm 0.040$

$\mathrm{CV}=2.11$

$\mathrm{CD}(1 \%)=0.08$

Legend: $\mathrm{Azu}=$ Azucena, Moro $=$ Moroberekan, $\mathrm{G}=$ Green, $\mathrm{A}=$ Albino, $-\mathbf{=}$ No regeneration 
Fig.1 Showing different steps of anther culture (1) anthers inoculated on N6 medium (2) callus obtained from anthers (3) shoot regeneration from androgenic callus

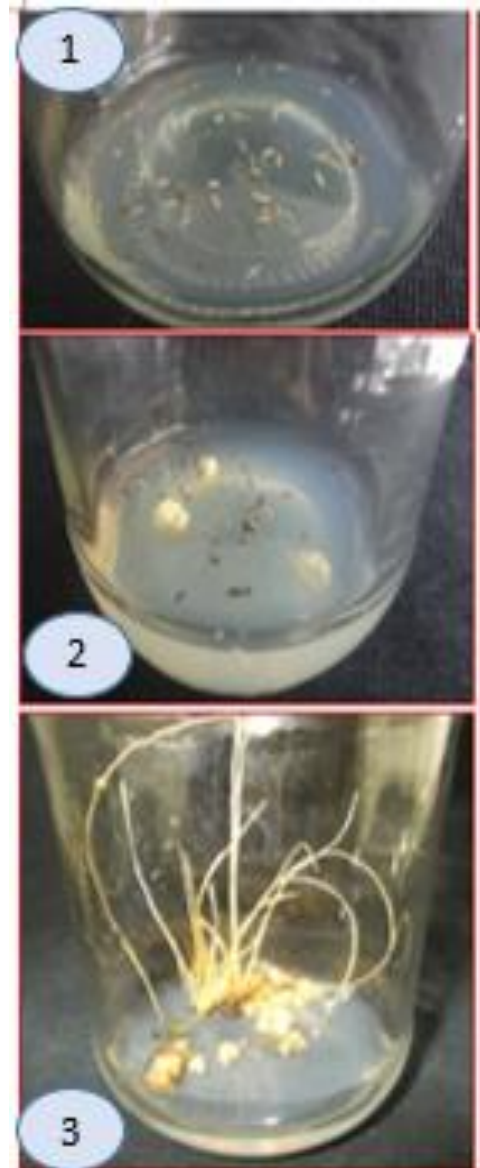

(A) Azucena

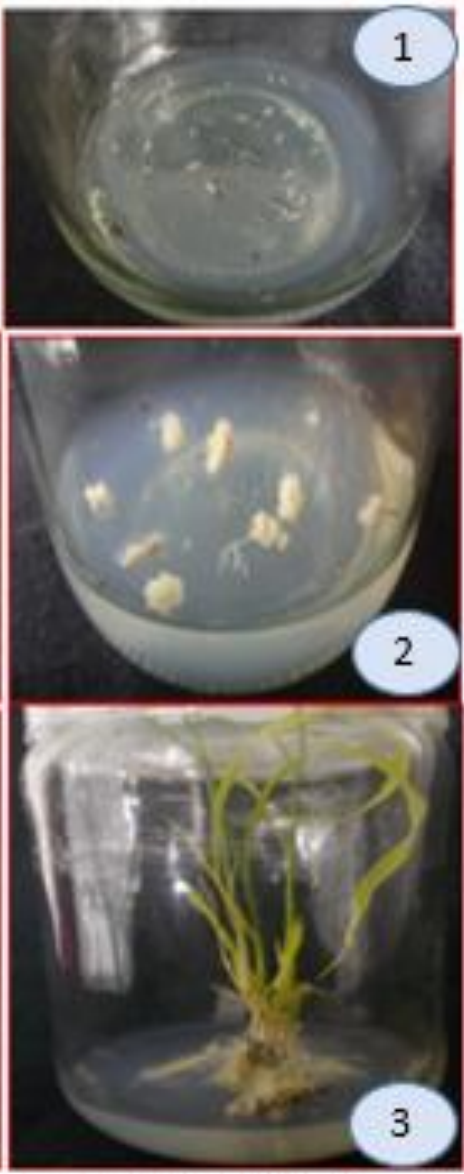

(B) Moroberekan
Auxins have been essential plant growth regulators for the induction of callus from anthers of cereals (Zhu et al., 1998) and the type and level of the auxin present in culture medium regulates the formation of callus. There was a significant difference among the growth regulator treatments. In the present study highest callus induction frequency $34.54 \%$ and $33.38 \%$ was observed in mean of treatment $\mathrm{T}_{4}(2 \mathrm{mg} / \mathrm{L} 2,4-\mathrm{D}+1 \mathrm{mg} / \mathrm{L}$ Kinetin) and $\mathrm{T}_{11}(1 \mathrm{mg} / \mathrm{L} 2,4-\mathrm{D}+2 \mathrm{mg} / \mathrm{L}$ $\mathrm{NAA}+0.5 \mathrm{mg} / \mathrm{L}$ Kinetin) respectively. However, the highest callus induction frequency was observed on $\mathrm{T}_{4}(49.99 \%)$ in Azucena [Fig. 1(2A)], whereas $\mathrm{T}_{11}(48.64 \%)$ in Moroberekan [Fig. 1(2B)]. These results are consistent with the findings of Gueye and Ndoye (2010) who observed $4.24 \%$ callus induction in IKP (Japonica) variety on N6 medium supplemented with $3 \mathrm{mg} / \mathrm{L} \mathrm{2,} \mathrm{4-D}$ and $1 \mathrm{mg} / \mathrm{L}$ NAA and $1 \mathrm{mg} / \mathrm{L}$ Kinetin. Herath et al., (2008) reported callus induction in $\mathrm{F}_{1}$ hybrids of indica (Bg 90-2) $\times$ japonica $(\mathrm{Hu}$ lo tao) in N6 media containing 2, 4-D + Kinetin. Dalpat et al., (2014) reported $6.66 \%$ callus induction in japonica variety Azucena in N6 media containing 2, 4-D, NAA and Kinetin. These studies indicate that genotype specific requirement of growth regulators is required to get a positive response and the marginal balance of the hormonal concentrations is important for callus induction. The variation 
in response with genotypes was also reported by Paulas and Rangasamy (1995) and Rangasamy et al., (1994).

The present study also agreement with TrejoTapia et al., (2002) reported auxins were essential for the induction of callus from anthers and suggested that the type and concentration of auxins have influence on the callus induction. Among the callus induction treatments, the time taken for callus induction was varied from 6-13 weeks. The colour of calli was yellow and white in both the varieties. In Azucena, white calli was produced in eight treatments $\left(\mathrm{T}_{1}, \mathrm{~T}_{5}, \mathrm{~T}_{6}, \mathrm{~T}_{8}\right.$, $\mathrm{T}_{10}, \mathrm{~T}_{11}, \mathrm{~T}_{15}$ and $\mathrm{T}_{16}$ ) and yellow calli was produced in the rest of the six treatments. Whereas, in Moroberekan, white calli was produced in eight treatments $\left(T_{2}, T_{3}, T_{6}, T_{8}\right.$, $\mathrm{T}_{10}, \mathrm{~T}_{12}, \mathrm{~T}_{14}$, and $\mathrm{T}_{15}$ ) and yellow calli was produced in the rest of the seven treatments. Furthermore, in Azucena variety, friable callus was observed in only one treatment $\left(\mathrm{T}_{14}\right)$ while in Moroberekan, friable callus was observed in two treatments $\left(T_{5}\right.$ and $\left.T_{11}\right)$ and remaining treatments calli were compact. These results supporting the earlier studies on callus texture and callus colour in rice anther culture (Ranaweera, 1998; Shahnewaz and Bari, 2004; Sengsai et al., 2007; Wagiran et al., 2008 and Shukla et al., 2014).

\section{Regeneration}

Androgenic calli of Azucena and Moroberekan were transferred to the regeneration medium containing various concentration and combinations of Kinetin, BAP and NAA. After 15 days of culture, these calli started differentiating into nodular structure and turned into green colour, which subsequently formed shoots (Table 2). Between the two varieties, higher shoot regeneration was recorded in Moroberekan (13.02 \%), followed by Azucena (7.01\%). Irrespective of the varieties, among the 19 shoot regeneration treatments, regeneration was observed in only six treatments $\left(T_{3}, T_{4}\right.$, $\mathrm{T}_{5}, \mathrm{~T}_{6}, \mathrm{~T}_{10}$ and $\left.\mathrm{T}_{16}\right)$. The mean of highest shoot regeneration frequency of $69.44 \%$ in $\mathrm{T}_{10}(0.5 \mathrm{mg} / \mathrm{L}$ Kinetin $+2 \mathrm{mg} / \mathrm{L} \mathrm{BAP}+1$ mg/L NAA) followed by treatment $\mathrm{T}_{16}(2$ $\mathrm{mg} / \mathrm{L}$ Kinetin $+1 \mathrm{mg} / \mathrm{L}$ BAP $+1 \mathrm{mg} / \mathrm{L}$ NAA) $(40.0 \%)$. The genotype of the donor plant has an important role in production of green plants through anther culture (Dewi et al., 2009). Among the two variety, an Azucena shoot regeneration was observed in only two treatments $\left(\mathrm{T}_{6}\right.$ and $\left.\mathrm{T}_{10}\right)$ but in both the treatments shootlets were albino. However, in Moroberekan, regeneration was observed in five treatments $\left(T_{3}, T_{10}\right.$ and $\left.T_{16}\right)$ with green shoots, remaining two treatments were produced albino shoot. Highest shoot regeneration frequency $(83.33 \%)$ was recorded in Azucena in $\mathrm{T}_{10}$ containing 0.5 $\mathrm{mg} / \mathrm{L}$ Kinetin $+2 \mathrm{mg} / \mathrm{L}$ BAP $+1 \mathrm{mg} / \mathrm{L}$ NAA but the shootlets were albino [Fig. 1(3A)]. Similar results were obtained by Shaukat, (2004) in Xiushui 11 and XC 95 rice genotypes and also by Sen and Singh, (2011) in Boro rice hybrids. However, in Moroberekan highest shoot regeneration frequency $(80.0 \%)$ was recorded in $\mathrm{T}_{16}$ containing $2 \mathrm{mg} / \mathrm{L}$ Kinetin $+1 \mathrm{mg} / \mathrm{L}$ BAP +1 $\mathrm{mg} / \mathrm{L}$ NAA and the shootlets were green [Fig. 1(3B)]. The present study indicates that highest regeneration was obtained in medium containing BAP, Kinetin and NAA. Similar finding were made by earlier workers (Asaduzzaman et al., 2003; Xa and Lang, 2011; Sah and Kaur, 2013; Mohiuddin et al., 2014 and Kushal et al., 2015). Furthermore, in several treatments no shoot regeneration was observed. Production of albino plants is one of the most frequent and conspicuous in rice anther culture. Several factors which influence the emergence of albino plants were reported to be: genotype and physiological status of the anther donor plants, developmental stage of microspores, culture temperature for callus induction, cold pre- 
treatment of anther, light intensity during culture, callus selection, growth regulator combination and sucrose concentration in combination with growth regulators. The proportion of albino plants among anther derived regenerated rice plants were reported from 5 to $90 \%$ in different japonica cultivars (Wang et al., 1981; Yamagishi et al., 1998). Time taken for regeneration in the two varieties range from 21 to 77 days. Between the two varieties, Moroberekan has responded first than Azucena for regeneration. Among the regeneration treatments, earliest regeneration was observed in $\mathrm{T}_{10}(0.5 \mathrm{mg} / \mathrm{L}$ Kinetin $+2.0 \mathrm{mg} / \mathrm{L} \mathrm{BAP}+10 \mathrm{mg} / \mathrm{L} \mathrm{NAA})$ it took less time for regeneration (21 days) and $\mathrm{T}_{5}$ regeneration treatment $(2 \mathrm{mg} / \mathrm{L}$ Kinetin + $0.5 \mathrm{mg} / \mathrm{L}$ NAA) taken more time for regeneration (77 days) in Moroberekan. However, in Azucena time taken for regeneration range from 28 to 35 days in $\mathrm{T}_{10}$ and $\mathrm{T}_{6}$ treatments respectively.

In conclusion, the present study indicates that both steps callus induction and regeneration efficiency in anther culture of rice varieties were genotype dependent, their response was different with same concentration of growth regulator.

\section{Acknowledgements}

Authors would like to thanks Dr. H. E. Shashidhar for providing seed materials. Avinash Sharma acknowledges DBT-HRD, New Delhi, India for providing fellowship during M.Sc. program.

\section{References}

Afza, R. Shen, M.E.I. Zapata, F.J. Xie, Fundih, J.K. Lee, K. Mucino, E.B. and Kodym, A. 2000. Effect of spikelet position on rice anther culture efficiency. Plant Sci., 153: 155-159.
Asaduzzaman, M. Bari, M.A. Rahman, M.H. Khatun, N. Islam, M.A. and Rahman, M. 2003. In vitro plant regeneration through anther culture of five rice varieties. Onl. J. Biol. Sci., 3(2): 167171.

Balachandran, S.M. Sarma, N.P. and Siddiq, E.A. 1999. Inheritance of anther culture response in rice. Curr. Sci., 77(7): 962967

Brown, D.C.W. and Thorpe, T.A. 1995. Crop improvement through tissue culture. World J. Microbiol. Biotechnol., 11: 409-415.

Cai, X.S. and Chen, L.Z. 1984. The effects of cold shock and liquid medium on callus formation in rice anther culture. J. Agri. Res., 33(1): 24-29.

Chen, H. and Qin, R.Z. 2008. Analysis of different effectors enhancing the anther culture ability of autotetraploid japonica rice. J. Agrl. Sci. Tech., 10(3): 90-96.

Chen, Q.F. Wang, C.L. Lu, Y.M. Shen, M. Afza, R. Duren, M.V. and Brunner, H. 2001. Anther culture in connection with induced mutations for rice improvement. Euphytica, 120: 401-408.

Chung, G.S. 1987. Application of anther culture technique for rice (Oryza sativa L.) improvement. In: Proceeding of Korea-China Plant Tissue Culture Symposium. November 17-23, Suweon, Korea, Society of Plant Tissue Culture, Acad. Sin., pp. 36-56.

Claparols, I. Santos, M.A. and Torne, J.M. 1993. Influence of some exogenous amino acids on the production of maize embryogenic callus and endogenous amino acid content. Plant Cell Tiss.Org. Cult., 34: 1-11.

Dalpat, L. Shashidhar, H.E. Godwa, P.H.R. and Ashok T.H. 2014. Callus induction and regeneration from in vitro anther culture of rice (Oryza sativa L.). Int. J. Agrl. Envir. Biotechnol., 7(2): 213-218. 
Dewi, I.S. Purwokob, B.S. Hajrial, A. Somantria, I.H. and Chozinb M.A. 2009. Plant regeneration from anther cultures of several genotypes of indica rice tolerant to aluminium toxicity. IPnldaonnt erseigaenn eJroautrionn froof mA garnitchuelrtu cruel, 1: 1-5.

Faostat. 2014. Rice market monitor, statistical data base, food and agricultural organization (FAO) of the United Nations, Rome, http//www.fao.org.

Gueye, T. and Ndir, K.N. 2010. In vitro production of double haploid plants from two rice species (Oryza sativa L. and Oryza glaberrima Steudt.) for the rapid development of new breeding material. Scient. Res. Ess., 5(7): 709713.

Gupta, H.S. and Borthakar, D.N. 1987. Improved rate of callus induction from rice anther culture following microscopic staging of microspores in iron-alum-haeraatoxylin. Theor. Appl. Genet., 74: 95-99.

He, T. Luo, K. Han, S.H. and Guo, X.X. 2004. Selection of high green-plant regenerating lines through rice anther culture. In: Tissue culture and Transformation (ed. Khush, G. S., Brar, D. S. and Hardy, B.). Advances in Rice Genetics, IRRI, Manila, Philippines, pp. 509-511.

He, T. Yang, Y. Tu, S.B. Yu, M.Q. and Li, X.F. 2006. Selection of interspecific hybrids for anther culture of indica rice. Plant Cell Tiss.Org.Cult., 13: 484-489.

Heberle-Bors, E. Stoger, E. Toraev, A. Zarsky, V. and Vicente, O. 1996. In vitro pollen cultures progress and perspectives. In: Pollen Biotechnology Gene Expression and Allergen Characterization, Mohapatra, S. S., Knox, R. B., (eds.), Chapman and Hall, New York, pp. 85-109.

Herath, H.M.I. Bandara, D.C. Samarajeewa, P.K. and Wijesudara, D.S.A. 2008. The effect of plant growth regulators on anther culture response and plant regeneration in selected Sri Lankan indica varieties, japonica varieties and their inter-subspecific hybrids. Trop. Agril Res., 20: 243-250.

Joong, H.L. and Seung, Y.L. 2002. Selection of stable mutants from cultured rice anthers treated with ethyl methane sulfonic acid. Plant Cell Tiss. Org. Cult., 71: 165-171.

Kaushal, L. Sharma, R. Balachandran, S.M. Ulaganathan, K. and Shenoy, V. 2014. Effect of cold pretreatment on improving anther culture response of rice (Oryza sativa L.). J. Exp. Biol. Agrl. Sci., 2: 234-241.

Khush, G.S. 2005. What it will take to Feed 5.0 Billion Rice consumers in 2030. Plant Mol. Biol., 59: 1-6.

Mercy, S.T. and Zapata, F.J. 1986. Effect of pollen development stage on callus induction and its relation to auricle distance in two rice varieties. Int. Rice Res., Newsletter, 11: 23-24.

Mohiuddin, A. K. Karim, N. H. and Sultana, S.: Development of improved doubledhaploids through anther culture of indica rice (Oryza sativa L.). Annals of Biological Res., 10: 6-13 (2014).

Niroula, R.K. and Bimb, H.P. 2009. Effect of genotype and callus induction medium on green plant regeneration from anther of Nepalese rice cultivars. Asian $J$. Plant Sci., 8: 368-374.

Pande, H. 1997. Androgenesis in anther cultures of indica cultivar of Oryza sativa L. Ph.D. Thesis, University of Delhi.

Paulas, S.D. and Rangasamy, S.R.S. 1995. Hormonal and genotypic influence on callus induction in rice. Oryza, 32: 245249.

Prabhu, K.N. 2013. Anther culture studies in rice (Oryza sativa L.). M.Sc. (Agri.) 
Thesis, University Agricultural Sciences, Bangalore.

Priyadarshi, R. and Shenoy, V. 2015. Auxin to improve green plant regeneration of rice anther culture. Int. J. Agri. Crop Sci., 8(1): 15-26.

Ranaweera, K.K.D.S. 1998. The effect of genotype and media supplements on callus induction and plant regeneration in rice anther culture. J. Sabaragamuwa Univer., 1: 87-92.

Rangasamy, S.R.S. Paulas, S.D. Ramaswamy, N.M. and Manonmani, S. 1994. Progress in rice anther culture research and application. Rockefeller rice biotechnology network programme, Annual report 1993-94. National Research Centre for Plant Biotechnology, IARI, New Delhi.

Reed, S.M. 2005. Haploid Cultures. In: Plant Development and Biotechnology, pp. 225-234.

Sah, B.P. 2008. Response of genotypes to culture media for callus induction and regeneration of plants from rice anthers. Scientific World, 6: 37-43.

Sah, S.K. and Kaur, A. 2013. Genotype independent tissue culture base line for high regeneration of japonica and indica rice. Res. J. Biotech., 8(12): 9698.

Sen, C. Singh, R.P. Singh, M.K. and Singh, H.B. 2011. Effect of cold pretreatment on anther culture of boro rice hybrids. Int. J. Plant Repro. Biol., 3: 69-73.

Sengsai, S. Peyachoknagu, S. Sripichitt, P. Thongpan, A. and Pongtongkam, P. 2007. Anther culture of $\mathrm{BC}_{1} \mathrm{~F}_{1}$ (KDML105//IRBB5/KDMl105) hybrid to produce bacterial blight resistance doubled haploid rice. Kasetsart J. Nat. Sci., 41: 251-261.

Shahnewaz, S. and Bari, M.A. 2004. Effect of concentration of sucrose on the frequency of callus induction and plant regeneration in anther culture of rice
(Oryza sativa L.). Plant Tiss. Cult., 14(1): 37-43.

Shukla, R. Dube, A. and Koshy, E.P. 2014. Production of high quality embryogenic callus of rice. The Bioscan, 9(3): 10771080.

Sunderland, N. and Dunwell, J.M. 1974. Pathways in pollen embryogenesis. In Tissue culture and plant science. Tiss. Cul. and Plant Sci., 141-16.

Tadesse, W. Tawkaz, S. Ingaki, M.N. Picard, E. and Baum, M. 2013. Methods and applications of doubled haploid technology in wheat breeding. ICARDA, Aleppo, Syria, pp. 36.

Touraev, A. Indriato, A. Wratschko, I. Vicente, O. and Heberle-Bors, E. 1996. Efficient microspore embryogenesis in wheat (Triticum aestivum L.) induced by starvation at high temperature. Sexu. Plant Repro., 9: 209-215.

Trejo-Tapia, G. Amaya, U. M. Morales, G. S. Sanchez, A. D. J. Bonfil, B. M. Rodriguez-Monroy, M. and JimenezAparicio, A.: The effects of coldpretreatment, auxins and carbon source on anther culture of rice. Plant Cell Tiss. Org. Cult., 71: 41-46 (2002).

Wagiran, A. Ismail, I. Radziah, C. Zain, C.M. and Abdullah, R. 2008. Improvement of plant regeneration from embryogenic suspension cell culture of japonica rice. J. Biol. Sci., 1727(3048): 570-576.

Wang, C.C. Sun, C.S. Chu, C.C. Wu, S.C. 1981. Studies on the albino pollen plantlets of rice. Proceedings of symposium on plant tissue culture, 149160.

Xa, T.T.T. and Lang, N.T. 2011. Rice breeding for high grain quality through anther culture. Omonrice, 18: 68-72.

Xie, J. Gao, M. Cai, Q. Cheng, X. Shen, Y. and Zhuqing. 1995. Improved isolated microspore culture efficiency in medium with maltose and optimized growth regulator combination in 
japonica rice (Oryza sativa). Plant Cell Tiss. Org. Cult., 42: 245-250.

Xie, J.H. Gao, M.W. Liang, Z.Q. Shu, Q.Y. Cheng, X.Y. and Xue, Q. 1997. The effect of cold pretreatment on the isolated microspore culture and the free amino acid change of anthers in japonica rice (Oryza sativa L.). J. Plant Physiol., 151: 79-82.

Yamagishi, M. Otani, M. Higashi, M. Fukuta, Y. Fukui, K. Yano, M. and Shimada, T. 1998. Chromosomal regions controlling anther culturability in rice (Oryza sativa L.). Euphytica 103(2): 227-234.

Zapata, A.F J. Torrizo, L.B. and Ando, A. 2004. Current developments in plant biotechnology for genetic improvement: the case of rice (Oryza sativa L.). Wor. J. Microbio. Biotechnol., 11: 393-399.

Zhang, Z.H. 1989. The practicability of anther culture breeding in rice. In: Review of advances in plant biotechnology, CIMMYT, Mexico, IRRI, Philippines pp. 36-37.

Zhou, C. Yang, H. Yan, H. and Sheng, C. 1983. Factors affecting callus formation in unpollinated ovary culture of rice. In: Cell tissue culture technique for Cereal crop improvement, Beijing, China, pp. 81-94.

Zhu, D.Y. Sun, Z.X. Pan, X.G. Ding, X.H. Shen, X.H. Won, Y. Pan, H. Yin, J.H. Alejar, M.S. Torrizo, L.B. and Datta, S.K. 1998. Use of anther culture in hybrid rice breeding. Proceedings of the 3rd International Symposium of Hybrid Rice 14-16 Nov 1996. Hyderabad, India. In: Advances in Hybrid Rice Technology. IRRI, Manila, Philippines. 21: 265-281.

\section{How to cite this article:}

Avinash Sharma, Dalpat Lal, Monoj Sutradhar, Hansraj Pradhan and Nirupa Kumari. 2018. Indirect Regeneration of Japonica Rice (Oryza sativa L.) Varieties through Anther Culture. Int.J.Curr.Microbiol.App.Sci. 7(08): 667-677. doi: https://doi.org/10.20546/ijcmas.2018.708.072 